\title{
Studies for B-type Natriuretic Peptide Values and Its Association with Diastolic Echocardiographic Parameters
}

\author{
Seong-Jo Bae ${ }^{1}$, Kisang Kwon ${ }^{2}$, Eun Ryeong Lee ${ }^{2}$ \\ ${ }^{1}$ Department of Pathology, CHA University Medical Center, Gumi 39295, Korea \\ ${ }^{2}$ Department of Biomedical Laboratory Science, College of Sciences, Kyungwoon University, Gumi 39160, Korea
}

\section{B-type Natriuretic Peptide 수치와 이완기 심초음파 파라미터와의 연관성 연구}

\author{
배성조 ${ }^{1}$, 권기상 $^{2}$, 이은령 ${ }^{2}$ \\ ${ }^{1}$ 구미차병원 진단검사의학과, ${ }^{2}$ 경운대학교 임상병리학과
}

\begin{abstract}
The b-type natriuretic peptide (BNP) values and increase on functional disorder in the ventricle, and are used as an index to diagnose heart failure and predict the prognosis. BNP values is known to be relevant to dyssystole in congestive heart failure. This study aimed to identify correlation between the BNP values and the items that indicate the diastolic function in echocardiography. The research divided 188 patients who went through the BNP test and echocardiography in the hospital into the groups with the BNP values; <100, 100-300, 301-600, 601-900, and >901 pg/mL. As the BNP values increase, there was relevance with the echocardiography items of ejection fraction, size of left atrium, E velocity, A velocity, Deceleration time, E/A ratio, E', $A^{\prime}, S^{\prime}$ and $E / E^{\prime}$. In comparison on the groups divided based on the BNP values, E/E' had the highest relevance. The research also categorized 67 patients who diagnosed with heart failure. In comparison on the groups of the heart failure patients, the BNP values of the three groups of Grade I: 623.0 \pm 459.7 pg/mL, Grade II: $1013.2 \pm 1155.1 \mathrm{pg} / \mathrm{mL}$ and Grade III: $1693.4 \pm 1544.0 \mathrm{pg} / \mathrm{mL}$, respectively $(p<$ 0.01 ). As the grade was higher, there was a higher relevance with the echocardiography items of ejection fraction, size of left atrium, E velocity, A velocity, Deceleration time, E/A ratio, E', A', S' and $E / E^{\prime}(p<0.001)$. Higher BNP values had a higher relevance with the items that indicate the diastolic function in echocardiography and the BNP values of the Restrictive physiology group were the highest in echocardiography. So the BNP values was thought to be valuable to predict diastolic function of heart.
\end{abstract}

Key words: B-type natriuretic peptide, Diastolic heart failure, Echocardiography

This is an Open Access article distributed under the terms of the Creative Commons Attribution Non-Commercial License (http://creativecommons.org/licenses/by-nc/4.0) which permits unrestricted non-commercial use, distribution, and reproduction in any medium, provided the original work is properly cited.

Copyright @ 2016 The Korean Society for Clinical Laboratory Science. All rights reserved.
Corresponding author: Eun Ryeong Lee Department of Biomedical Laboratory Science, College of Sciences, Kyungwoon University, 730 Gangdong-ro, Sandong-myeon, Gumi 39160, Korea

Tel: 82-54-479-1284

Fax: 82-54-479-1280

E-mail:2457eun@naver.com

Received: November 1, 2016 Revised $1^{\text {st: }}$ : December 1, 2016 Revised 2 ${ }^{\text {nd }}$ : December 1, 2016 Revised $3^{\text {nd. }}$ : December 4, 2016 Revised $4^{\text {th. }}$ : December 4, 2016 Accepted: December 4, 2016
서 론

심장질환에 의한 사망비율은 2014년 통계청에서 발표한 사망 원인 중 2 위를 차지했으며, 허혈성 심질환과 더불어 심부전(heart failure)이 중요한 사망원인이다. 대표적인 심장질환인 심부전은 심장의 구조적 또는 기능적 이상으로 충만 기능이나 수축 기능이 감소하여 신체에 필요한 혈액을 제대로 공급하지 못하여 발생하는 질환을 말한다. 심부전의 경우 예후가 좋지 않아 경한 상태의 심부 
전(Grade I)을 진단받은 환자에서도 5년 이내 사망률이 $50 \%$ 에 이 른다[1].

혈중 B-type natriuretic peptide (BNP)는 심실의 용적 증가와 압력 과부하 등의 혈역학적 자극에 반응하여 심실 심근세포가 늘어 나면서(stretch) 주로 생성 분비되는 신경호르몬으로 신장에서 수 분 분비를 촉진시키고, 혈관 평활근에서 동맥과 정맥의 확장을 일 으켜 심장의 전부하를 감소시키는 역할을 한다[2,3]. BNP는 심실 의 기능 장애가 있는 경우 상승하며, 심부전을 가진 환자를 진단하 고 예후를 예측하는데 사용되는 지표이다[4,5]. 또한 급성 호흡곤 란이 있는 환자에서 심인성, 비심인성의 감별에도 유용한 것으로 알려져 있다[6].

심초음파 또한 비침습적인 방법으로 심장기능을 평가하는데 있 어 활발히 연구되고 있는 검사이며 심부전을 진단하는데 가장 유용 한 방법이지만 폐질환이 있거나 비만하면 적절한 검사가 이루어 질 수 없는 단점을 가지고 있으므로 심부전 진단에 있어 심초음파와 $\mathrm{BNP}$ 를 함께 측정하면 심부전 진단에 매우 유용하다[6]. 심부전 진 단에서 BNP와 더불어 심초음파를 측정하는 경우, 승모판 초기 이 완기 속도(transmitral early diastolic velocity, E velocity)와 조 직 도플러를 이용한 승모판륜의 초기 이완기 속도(tissue doppler early diastolic mitral annular velocity, E'), 그리고 두 항목의 비 율(E/E'), 좌심실 충만압 측정 등 새로운 인자가 사용되고 있다 $[7,8]$.

심부전은 임상적으로 심근의 수축기능의 장애로 좌심실 구혈률 (ejection fraction, $\mathrm{EF}$ )이 감소하는 수축성 심부전과 좌심실 구혈 률은 정상으로 유지되면서 심실의 이완기능이 장애를 일으켜 좌심 실 충만압이 상승하는 이완성 심부전으로 구분할 수 있다.

심근이 이완되면 좌심실 내강은 길어지면서 옆으로 확장하게 된 다. 승모판륜의 종축 방향 움직임이 심근의 이완속도와 상관관계가 있다는 것이 밝혀졌다[9,10]. 조직 도플러 영상을 통해서 승모판륜 의 초기 이완기 속도(E')를 측정하는 것은 좌심실 이완 기능에 대한 심초음파에서 중요한 부분을 차지한다[9-11]. 또한 승모판륜에서 의 조직 도플러는 전부하(preload) 같은 혈역학적 변화에 비교적 적은 영향을 받는 것으로 연구되고 있다[10,12].

전통적으로 연구진들은 심부전의 증상을 설명하기 위해서 수축 기능 이상에 대해 많은 연구를 해왔다. 그러나 심부전의 진행과 예 후에 영향을 주는 것이 이완 기능 장애라는 사실이 점차 밝혀지고 있다. 심부전이 문제가 되는 것은 좌심실 구혈률이 정상이면서 심 실의 이완 기능에 장애가 있을 때이다[13,14]. BNP 증가는 울혈성 심부전에서 수축기 장애 정도와 연관성이 있는 것으로 알려져 있지 만, BNP와 심실 이완 기능의 상관관계에 대한 연구는 활발히 이루 어지지 않고 있다[15]. 본 연구는 BNP 결과와 심초음파에서 이완
기능을 나타내는 항목이 어떠한 상관관계가 있는지 알아보고자 한다.

\section{대상 및 방법}

\section{1. 연구대상}

B-type Natriuretic Peptide (BNP)와 심초음파를 동일한날 같 이 실시한 환자 188 명을 대상으로 하였다. 본 연구는 경운대학교 생명윤리심의위원회(IRB)의 승인을 받았다(KWU-2016-03).

\section{2. 연구방법}

1) BNP 결과와 심초음파 이완기 항목과의 비교

2016 유럽심장학회(European Society of Cardiology, ESC) 가 이드라인에서는 BNP의 적정 cut-point를 $100 \mathrm{pg} / \mathrm{mL}$ 로 했을 때 negative predictive value가 90\%이므로 진단시 배제하는 도구로 써 적용하자는 것이다. Cleveland clinic에서 사용하고 있는 분류 에 따라서 $100 \mathrm{pg} / \mathrm{mL}$ 이하, $300 \mathrm{pg} / \mathrm{mL}$ 이하, $600 \mathrm{pg} / \mathrm{mL}$ 이하, $900 \mathrm{pg} / \mathrm{mL}$ 이하, $900 \mathrm{pg} / \mathrm{mL}$ 초과 그룹으로 분류하여 심초음파의 좌심실 구혈률(left ventricle ejection fraction, $\mathrm{EF}$ )과 좌심방 내경 (left artrial dimension), 그리고 이완기 항목인 승모판 초기 이완 기 속도 E velocity (transmitral early diastolic velocity), 후기 이 완기 속도 A velocity (atrial contraction, late diastolic velocity), DT (deceleration time of the E velocity), E/A ratio, 승모판륜의 초기 이완기 속도 $\mathrm{E}^{\prime}$ (tissue doppler early diastolic mitral annular velocity), A' (filling velocity after atrial contraction), $\mathrm{S}^{\prime}$ (systole velocity), E/E'들과 비교하였다.

2) BNP 결과와 심부전 환자들의 심초음파 이완기 항목과의 비교 188 명중 심부전 진단을 받은 환자 67명을 미국심초음파학회 (American Society of Echocardiography, ASE)의 이완기등급의 실질적인 접근법에 따라 Relaxation abnormality (Grade I), Pseudonormalization (Grade II), Restrictive physiology (Grade III)로 분류하여 각 그룹을 심초음파의 EF, LA dimension 그리고 이완기 항목 E velocity, A velocity, E/A ratio, E', A', S', $\mathrm{E} / \mathrm{E}^{\prime}$ 들과 비교하였다.

\section{3) 혈청 B-type Natriuretic Peptide (BNP) 검사}

$\mathrm{BNP}$ 검사는 ethylene diamine tetraacetic acid (EDTA)가 함 유된 tube에 전혈을 채취하여 10 분간 방치 후 $3000 \mathrm{rpm}$ 으로 10 분 간 원심분리 후 면역자동측정기 (ADVIA CENTAUR, Siemens, Surrey, Germany)로 검사하였다. 
4) 심초음파(echocardiography)

심초음파 측정은 미국심초음파학회의 권고안에[16] 따라서 초 음파장비(iE33 xMATRIX Ultrasound System, Philips, Eindhoven, Netherlands)로 시행하였다. 이면성 심초음파의 심첨부 4 방 단면 도에서 좌심실 구혈률(left ventricle ejection fraction, $\mathrm{EF})$ 은 modified Simpson's method에 의하여 평가 하였고(Figs. 1, 2) [16], 좌심방 크기(left atrial dimension)는 흥골연 장축 단면도 (parasternal long axis view)에서 측정하였다(Fig. 3). 승모판 유 입혈류는 도플러빔을 혈류의 방향과 평행하게 샘플볼륨을 승모판 엽 첨부(leaflet tip)에 두고 간헐파(pulse wave) 도플러를 사용하 여 승모판 초기 이완기 속도 E velocity (transmitral early diastolic velocity), A velocity (atrial contraction, late diastolic velocity), DT (deceleration time of the E velocity), E/A ratio를 평가하였다(Fig. 4) [18]. 이어서 승모판륜(septal mitral annulus) 에서 1 2 mm 샘플 볼륨을 위치시키고 조직 도플러 영상(tissue doppler imaging)을 이용하여 승모판륜의 초기 이완기 속도 $\mathrm{E}^{\prime}$

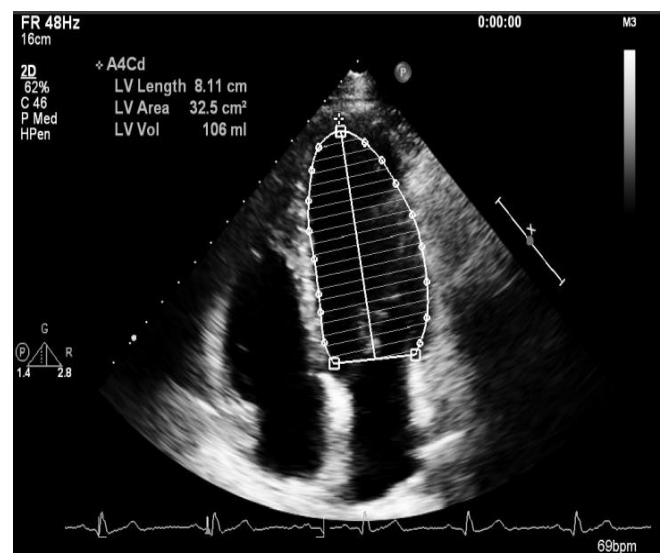

Fig. 1. Left ventricular diastole volume in the 4-chamber view of the heart, which was evaluated by modified Simpson's method.

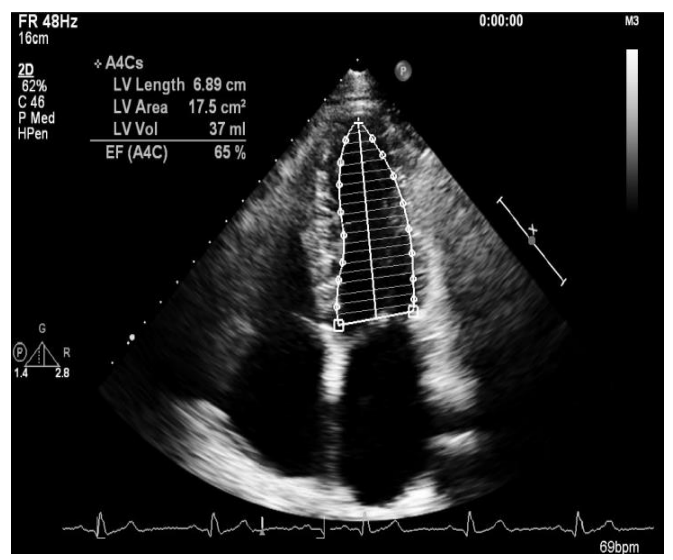

Fig. 2. Left Ventricle systole volume in the 4-chamber view of the heart, which was evaluated by modified Simpson's method. (tissue doppler early diastolic mitral annular velocity), A' (filling velocity after atrial contraction), $\mathrm{S}^{\prime}$ (systole velocity), E/E'을 구하였다(Fig. 5).

\section{5) 통계적 방법}

$\mathrm{BNP}$ 수치에 따른 차이를 알아보기 위하여 BNP 결과를 5 개 집단 으로 나누었고, 심부전 진단을 받은 환자들의 grade에 따른 차이를 알기 위하여 심초음파 결과로 환자들을 3 개의 grade로 분류하였으 며, 집단 간 차이를 비교하기 위하여 one-way analysis of variance (ANOVA)를 이용하였고, 다중비교로는 turky HSD, Games-Howell 사후검증을 사용하였다. 유의성의 판정은 $p$ 값이 0.05 미만으로 하였으며, 모든 통계 처리는 SPSS version 17.0. (SPSS, Chicago, IL, USA)을 사용하였다.

\section{결 과}

\section{BNP 결과와 심초음파 이완기 항목과의 비교}

대상 환자는 188 명(남 75 , 여 113)으로 BNP 결과 $100 \mathrm{pg} / \mathrm{mL}$ 이 하는 22 명(평균 연령 $73.4 \pm 15.0$ 세), $300 \mathrm{pg} / \mathrm{mL}$ 이하는 50 명

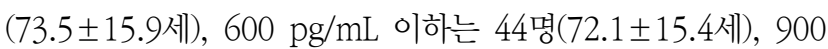
$\mathrm{pg} / \mathrm{mL}$ 이하 31 명(75.3 \pm 9.7 세), $900 \mathrm{pg} / \mathrm{mL}$ 초과 41 명(72.8 \pm 12.9 세)이었다.

$\mathrm{BNP}$ 결과에 따라 분류한 그룹에서 심초음파 이완기 항목과의 비교는 $\mathrm{EF}(p<0.001)$, LA dimension ( $p=0.004)$, E vel. ( $p=0.001)$, E/A ratio ( $p=0.006)$, DT $(p<0.001), \mathrm{A}^{\prime}(p<0.001), \mathrm{S}^{\prime}(p<0.001)$, $\mathrm{E} / \mathrm{E}^{\prime}(p<0.001)$ 에서 유의한 상관관계가 있었다. A vel.와 $\mathrm{E}^{\prime}$ 은 유 의성이 없었다 $(p=0.634, p=0.318)$. 좌심실 구혈률 $(\mathrm{EF})$ 은 수축성 을 나타내는 지표이긴 하지만 BNP 결과가 높아질수록 음의 상관관 계를 잘 보여주었는데 $(p<0.001) 100 \mathrm{pg} / \mathrm{mL}$ 이하 그룹에서는 좌

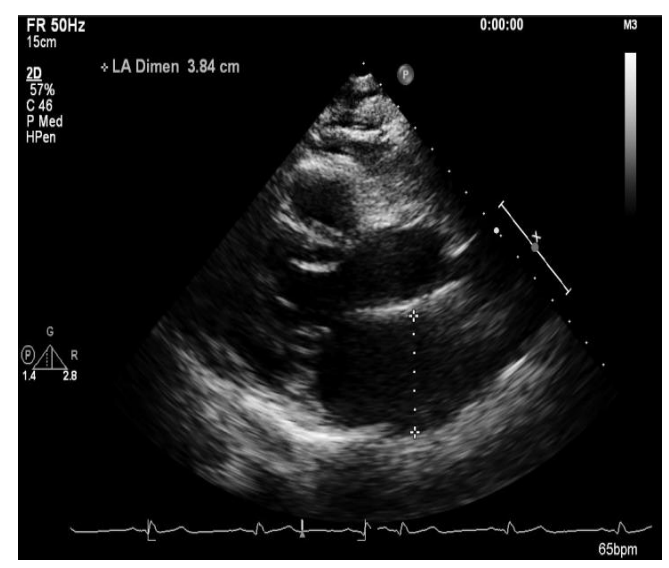

Fig. 3. Left atrial dimension in a parasternal long axis view. 


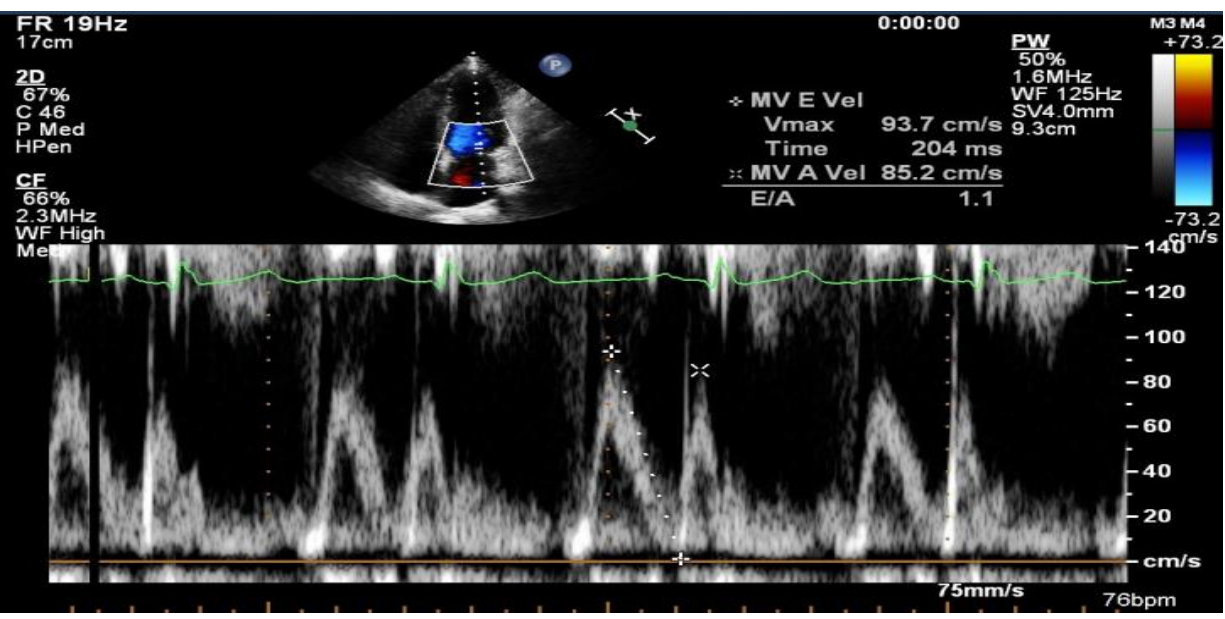

Fig. 4. Mitral inflow blood flow was measured by using a pulse wave Doppler with a sample volume in the leaflet tip parallel to the direction of the flow of blood and measuring mitral valve diastolic velocity (E velocity) (Atrial contraction, late diastolic velocity), DT (deceleration time of the $E$ velocity), and $E / A$ ratio.

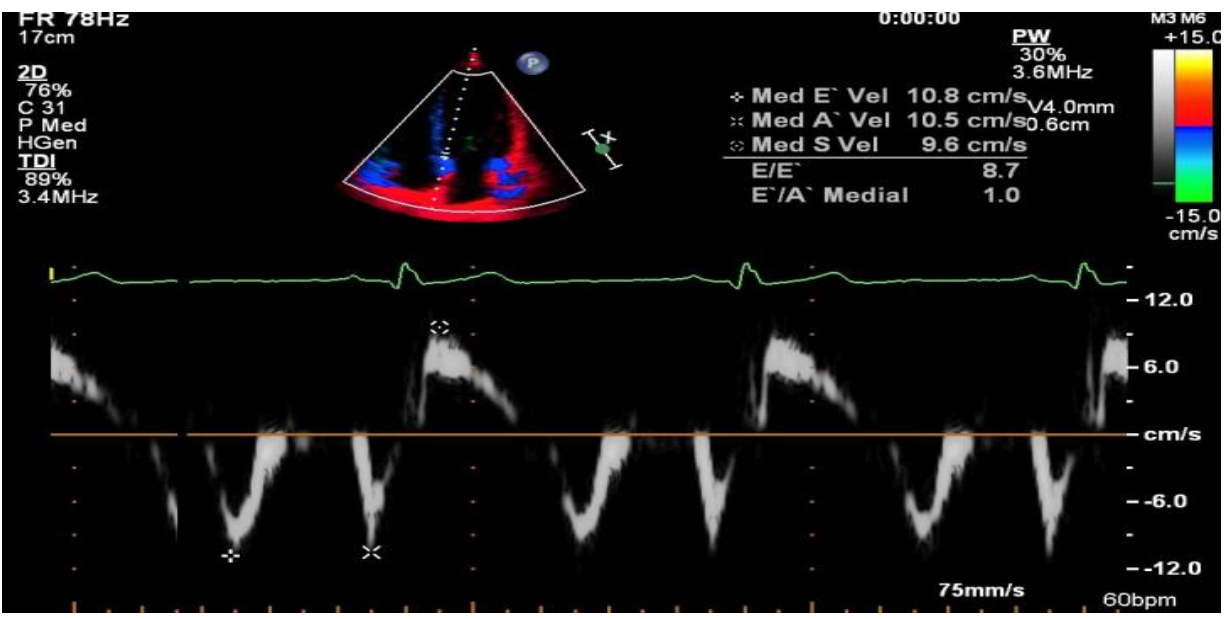

Fig. 5. Mitral annulus and tissue doppler imaging was used to determine the early diastolic mitral annular velocity $E$ ' Velocity after atrial contraction, $\mathrm{S}$ '(systole velocity), E/E'.

심실 구혈률의 평균이 $56.6 \pm 8.8 \%, 300 \mathrm{pg} / \mathrm{mL}$ 이하 그룹의 평균 은 $54.4 \pm 12.2 \%, 600 \mathrm{pg} / \mathrm{mL}$ 이하 그룹에서의 평균이 $52.6 \pm 11.4 \%$ 으로 정상 수축 기능을 보여주었고, $601 \mathrm{pg} / \mathrm{mL}$ 이상 그룹에서 평 균이 $48.6 \pm 16.2 \%$ 로 좌심실의 수축기능이 감소됨을 보여주었다. 그룹간의 비교에서는 $300 \mathrm{pg} / \mathrm{mL}$ 이하, $600 \mathrm{pg} / \mathrm{mL}$ 이하, 900 $\mathrm{pg} / \mathrm{mL}$ 이하 그룹 간은 심초음파 이완기 항목들과 유의한 차이가 없었다. 반면 그룹 간 가장 많은 유의성을 보여준 항목은 E/E'이었 다(Table 1).

\section{BNP 결과와 심부전 환자들의 심초음파 이완기 항목과의 비교}

심부전 진단을 받은 환자는 67명(남 19, 여 48), 그렇지 않은 환 자는 121 명(남 56, 여 65)이었다. 심부전 진단을 받은 67명을 심초 음파의 이완기 패턴으로 구분한 그룹에서는 Relaxation abnormality (Grade I) 23명, Pseudonormalization (Grade II) 23명, Restrictive physiology (Grade III) 21명이었다. BNP 결과는 Grade I 그룹 에서 평균 $623.0 \pm 459.7 \mathrm{pg} / \mathrm{mL}$, Grade II 그룹에서 평균

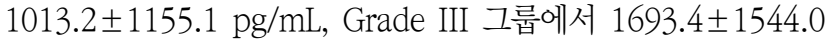
$\mathrm{pg} / \mathrm{mL}$ 로 진행 정도에 따른 유의성이 있었다( $p=0.01)$. Grade가 올 라갈수록 심초음파 항목 $\mathrm{EF}$ ( $p=0.006)$, LA dimension ( $p=0.001)$, Evelocity $(p<0.001)$, A velocity $(p=0.012)$, E/A ratio $(p<0.001)$, $\mathrm{DT}(p=0.001), \mathrm{A}^{\prime}(p<0.001), \mathrm{E} / \mathrm{E}^{\prime}(p<0.001)$ 와상관관계가 있었 다. 그러나 $\mathrm{E}^{\prime}$ 와 $S^{\prime}$ 은 유의성이 없었다 $(p=0.695, p=0.143)$. 그룹간 의 비교에서 세 그룹 모두 의미 있는 결과를 보여준 심초음파 이완 기 항목은 E/A ratio 와 $\mathrm{A}^{\prime}$ 이었다(Table 2).

\section{고 찰}

B-type natriuretic peptide (BNP)는 17-아미노산 고리 구조를 가진 32 아미노산 펩타이드로 좌심실벽 세포 조직에서 분비되고, 자극에 반응하여 급속히 상승하며 반감기는 20 분 정도이다 $[18,19] . \mathrm{BNP}$ 의 분비는 심실의 용적 과부하에 따른 좌심실벽의 확 장과 증가된 긴장도에 따라 분비량이 증가된다[20]. 분비된 $\mathrm{BNP}$ 는 
398 Seong-Jo Bae, et al. Studies for B-type Natriuretic Peptide Values and Its Association with Diastolic Echocardiographic P

Table 1. Comparison of the BNP values and echocardiographic diastolic parameters

\begin{tabular}{|c|c|c|c|c|c|c|c|}
\hline BNP level & $A$ & B & C & D & E & F-distribution & $p$-value \\
\hline Number & 22 & 50 & 44 & 31 & 41 & & \\
\hline BNP (pg/mL) & $43.1 \pm 24.1$ & $187.3 \pm 56.4$ & $430.8 \pm 83.7$ & $737.0 \pm 83.0$ & $1866.0 \pm 1098.0$ & 77.574 & $<0.001$ \\
\hline Age (years) & $73.4 \pm 15.0$ & $73.5 \pm 15.9$ & $72.1 \pm 15.4$ & $75.3 \pm 9.7$ & $72.8 \pm 12.9$ & 0.242 & 0.914 \\
\hline $\mathrm{EF}(\%)$ & $56.6 \pm 8.8$ & $54.4 \pm 12.2$ & $52.6 \pm 11.4$ & $48.6 \pm 16.2$ & $34.1 \pm 14.1$ & 18.690 & $<0.001$ \\
\hline LA size $(\mathrm{cm})$ & $3.8 \pm 0.7$ & $4.1 \pm 0.7$ & $4.1 \pm 0.7$ & $4.3 \pm 0.8$ & $4.6 \pm 0.9$ & 4.056 & 0.004 \\
\hline E vel. $(\mathrm{cm} / \mathrm{s})$ & $60.9 \pm 16.0$ & $78.9 \pm 28.3$ & $79.1 \pm 31.4$ & $84.2 \pm 31.4$ & $93.7 \pm 26.6$ & 5.121 & 0.001 \\
\hline A vel. $(\mathrm{cm} / \mathrm{s})$ & $88.0 \pm 19.9$ & $90.1 \pm 28.6$ & $88.0 \pm 31.9$ & $98.2 \pm 90.0$ & $81.3 \pm 29.4$ & 0.640 & 0.634 \\
\hline $\mathrm{E} / \mathrm{A}$ ratio & $0.8 \pm 0.4$ & $1.0 \pm 0.5$ & $1.0 \pm 0.5$ & $1.2 \pm 0.8$ & $1.4 \pm 0.7$ & 3.771 & 0.006 \\
\hline DT (ms) & $243.6 \pm 74.0$ & $232.8 \pm 66.2$ & $217.6 \pm 68.6$ & $209.1 \pm 68.7$ & $171.0 \pm 40.1$ & 7.065 & $<0.001$ \\
\hline$E^{\prime}(\mathrm{cm} / \mathrm{s})$ & $5.1 \pm 1.8$ & $4.9 \pm 1.8$ & $4.5 \pm 1.4$ & $4.7 \pm 1.7$ & $4.3 \pm 1.3$ & 1.186 & 0.318 \\
\hline $\mathrm{A}^{\prime}(\mathrm{cm} / \mathrm{s})$ & $9.4 \pm 1.9$ & $8.0 \pm 2.0$ & $7.8 \pm 2.1$ & $7.9 \pm 2.5$ & $6.4 \pm 2.3$ & 7.599 & $<0.001$ \\
\hline $\mathrm{S}^{\prime}(\mathrm{cm} / \mathrm{s})$ & $7.5 \pm 1.5$ & $7.0 \pm 1.5$ & $6.6 \pm 1.4$ & $6.2 \pm 1.6$ & $5.4 \pm 1.9$ & 8.055 & $<0.001$ \\
\hline$E / E^{\prime}$ & $12.6 \pm 3.7$ & $17.5 \pm 7.2$ & $19.4 \pm 8.4$ & $19.6 \pm 8.8$ & $23.3 \pm 9.4$ & 6.976 & $<0.001$ \\
\hline
\end{tabular}

$\mathrm{A}, \leq 100 \mathrm{pg} / \mathrm{mL} ; \mathrm{B}, \leq 300 \mathrm{pg} / \mathrm{mL} ; \mathrm{C}, \leq 600 \mathrm{pg} / \mathrm{mL} ; \mathrm{D}, \leq 900 \mathrm{pg} / \mathrm{mL} ; \mathrm{E},>900 \mathrm{pg} / \mathrm{mL}$.

Abbreviation: BNP, B-type natriuretic peptide; EF, ejection fraction; LA size, left atrium size; E vel, transmitral early diastolic velocity; A vel, atrial contraction late diastolic velocity; DT, deceleration time of the E velocity; E', tissue doppler early diastolic mitral annular velocity; $A^{\prime}$, filling velocity after atrial contraction; $S^{\prime}$, systole velocity.

Table 2. Comparison of the BNP values and echocardiographic diastolic parameters of heart failure patients

\begin{tabular}{lccccc}
\hline \multicolumn{1}{c}{ Grade } & Grade 1 & Grade 2 & Grade 3 & F-distribution & $p$-value \\
\hline Number & 23 & 23 & 21 & & \\
BNP (pg/mL) & $623.0 \pm 459.7$ & $1013.2 \pm 1155.1$ & $1693.4 \pm 1544.0$ & 5.014 & 0.010 \\
Age (years) & $78.7 \pm 7.5$ & $72.7 \pm 16.8$ & $70.3 \pm 11.2$ & 2.700 & 0.075 \\
EF (\%) & $44.7 \pm 14.8$ & $43.6 \pm 17.0$ & $30.2 \pm 16.1$ & 5.492 & 0.006 \\
LA size (cm) & $4.2 \pm 0.7$ & $4.7 \pm 0.4$ & $4.9 \pm 0.7$ & 7.593 & 0.001 \\
E vel. (cm/s) & $66.2 \pm 17.7$ & $102.3 \pm 24.4$ & $110.2 \pm 25.1$ & 24.203 & $<0.001$ \\
A vel. (cm/s) & $93.0 \pm 21.6$ & $109.2 \pm 100.2$ & $54.1 \pm 15.1$ & 4.732 & 0.012 \\
E/A ratio & $0.7 \pm 0.1$ & $1.2 \pm 0.3$ & $2.2 \pm 0.8$ & 56.826 & $<0.001$ \\
DT (ms) & $220.2 \pm 65.1$ & $221.8 \pm 67.4$ & $153.5 \pm 55.2$ & 8.270 & 0.001 \\
E' (cm/s) & $4.3 \pm 1.3$ & $4.3 \pm 1.4$ & $4.0 \pm 0.9$ & 0.365 & 0.695 \\
A' (cm/s) & $8.1 \pm 1.5$ & $6.2 \pm 1.7$ & $4.9 \pm 1.6$ & 22.456 & $<0.001$ \\
S' (cm/s) & $5.7 \pm 1.3$ & $5.6 \pm 1.3$ & $5.0 \pm 1.3$ & 2.009 & 0.143 \\
E/E' & $16.2 \pm 4.1$ & $25.7 \pm 8.8$ & $28.8 \pm 8.5$ & 17.450 & $<0.001$ \\
\hline
\end{tabular}

Abbreviation: Grade I, Relaxation abnormality; Grade II, Pseudonormalization; Grade III, Restrictive physiology; BNP, B-type natriuretic peptide; EF, ejection fraction; LA size, left atrium size; E vel, transmitral early diastolic velocity; A vel, atrial contraction late diastolic velocity; DT, deceleration time of the E velocity; $E^{\prime}$, tissue doppler early diastolic mitral annular velocity; $A^{\prime}$, filling velocity after atrial contraction; S', systole velocity.

원위 및 근위 세뇨관에서 나트륨의 배설을 증가시키고, 요량도 증 가시키며, 저혈압과 평활근의 이완을 유발시킨다[21]. 또한 심장 충만압(cardiac filling pressure)과 폐동맥압(pulmonary artery pressure)을 감소시키고 심박수를 정상화시킨다[22,23]. 최근 연 구에서는 BNP 수치가 심부전증의 중증도에 따라 비례하여 증가하 고, 좌심실의 기능과 밀접한 연관성이 있음이 알려지고 있다[24].

심부전은 심장 기능의 이상으로 인해 신체가 요구하는 에너지 대사를 심장이 충족시킬 만큼의 혈액순환을 감당하지 못하는 상태 이거나 적절하게 혈액순환을 하기 위해 심실 충만압이 증가되는 상 태이다. 심부전은 수축기 심부전과 이완기 심부전으로 분류하는데 많은 역학 연구에서 심부전증의 $30 \sim 50 \%$ 에서 좌심실의 수축기 기
능이 정상 소견을 보인다는 사실이 알려지면서, 이완기 심부전의 연구에 관심이 늘고 있다[25,26]. 수축기 기능이 정상인 심부전 환 자의 치료제 또한 울혈상태를 감소시키는 이뇨제의 사용 등은 수축 기 심부전 환자와 동일하지만 수축기 심부전 환자와 같이 장기 예 후를 호전시키는 약제도 드문 실정이다.

$\mathrm{BNP}$ 수치는 좌심실 기능 부전과 의미 있는 상관관계를 보여주 어 심부전 진단에 있어 많이 이용하고 있는데, 수축기 심부전 진단 에서 BNP의 임상적 유용성은 인정되고 있지만[27,28], 이완기 심 부전에서는 BNP의 진단의 정확성이 입증되지 못하고 있다. 또한 이완기 심부전의 진단 기준이 유럽 위원회와 미국이 서로 같지 않 다. 심초음파는 비침습적인 방법으로 심장 기능, 질병의 정도, 예후 
를 평가 할 수 있는 가장 유용한 검사이다[29]. 심부전 자체에 대한 진단 및 심부전의 원인에 대한 진단에도 중요한 기능을 하는 검사 이다. 심장의 수축기 장애는 주로 좌심실 구혈율의 감소, 심근 수축 력의 감소로 측정하고, 이완기 장애는 승모판엽 첨부에서 얻은 승 모판 유입혈류를 이용하여, E/A ratio, Deceleration time등을 이 용하여 확인할 수 있다. 아직 모든 지표들의 진단 기준치가 통일되 지 않은 실정이고 환자가 비만하거나 폐질환이 있는 경우 진단이 어려운 제한점이 있으나 심초음파 기준에 의한 심부전 진단이 가장 많이 사용되고 있다.

이면성 초음파와 더불어 조직 도플러 영상(tissue doppler imaging)의 이용도 많이 보편화 되어가고 있다. 조직 도플러 영상 은 1989년 Isaaz 등에 의해 처음 소개된 개념으로 혈류 도플러보다 진폭이 크고 낮은 주파수의 조직 도플러신호를 선택적으로 간헐파 도플러를 이용해 분석하는 검사법이다[30]. 이를 이용해 심근의 이 동속도를 측정할 수 있고 이완 기능을 쉽게 평가 할 수 있는 것으로 알려져 있다[10]. 심부전에서 BNP가 증가된다는 것은 이미 알려진 사실이지만, 주로 수축기 심부전에 대한 연구였고, 최근 이완기 장 애와 BNP와의 관계에 대한 연구가 진행되고 있다[15]. BNP로 이 완기 심부전을 진단할 수 있는지에 대해 294명을 대상으로 Doppler 심초음파 검사소견을 기준으로 한 연구에서 Lubien 등은 이완기능 장애의 진단율은 수축기능 장애 진단율과 비슷하였고 특 히 restrictive filling pattern을 보일 때 BNP 수치가 더 높았다고 보고하였다[31]. 본 연구에서도 심부전 진단을 받은 67 명 중 Restrictive physiology (Grade III) 그룹에서 BNP의 결과가 가장 높게 측정된 결과를 보여주었다.

본 연구의 제한점으로는 심부전 진단에 있어 수축성과 이완성을 분류하지 않았고 심초음파 결과만을 가지고 분류하였으며, 심부전 진단 환자가 67 명으로 많지 않았다. 또한 대상자의 평균 연령이 고 령으로 젊은 대상자의 연구가 필요하리라 여겨지며, 전체 188 명 대 상자의 기본 질환을 고려하지 않았기에 통계 분석에 영향을 줄 수 있다는 점이다. 추후좀 더 많은 이완기 심부전 진단을 받은 환자를 대상으로 BNP 결과와 심초음파의 이완기 항목들의 연구가 지속된 다면 BNP의 가치는 더욱 상승할 것이라 사료된다.

\section{요 약}

B-type natriuretic peptide (BNP)와 심초음파는 심부전 진단 과 예후를 판단하는 지표로써 수축 기능이상에 많은 연구를 했으 나, 본 연구에서는 BNP 결과와 심초음파 이완 기능을 나타내는 항 목의 상관관계를 알아보고자 한다. BNP 검사와 심초음파를 실시 한 188 명을 대상으로 BNP 결과에 따라 5그룹으로 분류하고, 심초
음파의 좌심실 구혈률, 좌심방 크기, E velocity, A velocity, Deceleration time, E/A ratio, E', A', S', E/E'와의 상관관계를 조사 하고, 그 중 심부전을 진단 받은 67명을 Relaxation abnormality (Grade I), Pseudonormalization (Grade II), Restrictive physiology (Grade III)로 등급을 분류하고 BNP 결과와 심초음파 항목을 비교 한 결과 BNP 수치가 상승할수록 심초음파 항목 중 좌심실 구혈률, 좌심방 크기, E/A ratio, Deceleration time, $\mathrm{A}^{\prime}, \mathrm{S}^{\prime}, \mathrm{E} / \mathrm{E}^{\prime}$ 와 유의한 상관관계가 있었다. 그룹간의 비교에서 $\mathrm{E} / \mathrm{E}^{\prime}$ 항목이 가장 좋은 유의 성을 보여주었다. 심부전 환자의 등급 분류에 따른 $\mathrm{BNP}$ 결과는 $623.0 \pm 459.7 \mathrm{pg} / \mathrm{mL}, 1013.2 \pm 1155.1 \mathrm{pg} / \mathrm{mL}, 1693.4 \pm 1544.0$ $\mathrm{pg} / \mathrm{mL}$ 로 유의성이 있었으며 $(p<0.01)$, 등급이 올라갈수록 심 초음파 항목 중 좌심실 구혈률, 좌심방 크기, $\mathrm{E}$ velocity, A velocity, E/A ratio, Deceleration time, $\mathrm{A}^{\prime}, \mathrm{E} / \mathrm{E}^{\prime}$ 와 상관관계가 있 었다 $(p<0.001)$. BNP 결과가 상승할수록 심초음파 이완기 항목과 유의성이 있었고, 심초음파에서 Restrictive physiology 그룹의 $\mathrm{BNP}$ 결과가 가장 높았다.

\section{Acknowledgements: None}

Funding: None

Conflict of interest: None

\section{References}

1. Mosterd A, Hoes AW, de Bruyne MC. Prevalence of heart failure and left ventricular dysfunction in the general population - The rotterdam study. Eur Heart J. 1999;20:447-455.

2. Yasue H, Yoshimura M, Sumida H, Kikuta K, Kugiyama K, Jougasaki M, et al. 1994. Localization and mechanism of secretion of B-type natriuretic peptide in normal subjects and patients with heart failure. Circulation. 1990:195-203.

3. De Lemos JA, McGuire DK, Drazner MH. B-type natriuretic peptide in cardiovascular disease. Lancet. 2003;362:316-322.

4. McDonagh TA, Robb SD, Murdoch DR, Morton JJ, Ford I, Morrison CE, et al. Biochemical detection of left-ventricular systolic dysfunction. Lancet. 1998;351:9-13.

5. Tsutamoto T, Wada A, Maeda K, Hisanaga T, Maeda Y, Fukai D, et al. Attenuation of compensation of endogenous cardiac natriuretic peptide system in chronic heart failure. Prognostic role of plasma brain natriuretic peptide concentration in patients with chronic symptomatic left ventricular dysfunction. Circulation. 1997;96:509-516.

6. Harrison A, Morrison LK, Krishnaswamy P. B-type natriuretic peptide predicts future cardiac events in patients presenting to the emergency department with dyspnea. Ann Emerg Med. 2002;39:131-138.

7. Dokainish H, Zoghbi WA, Lakkis NM, Quinones MA, Nagueh SF. Comparative accuracy of B-type natriuretic peptide and tissue Doppler echocardiography in the diagnosis of congestive heart 
failure. Am J Cardial. 2004;93:1130-1135.

8. Dokainish H, Zoghbi WA, Al-Bakshy FA, et al. Optimal non-invasive assessment of LV filling pressures: a comparison of tissue Doppler echocardiography and BNP in patients with pulmonary artery catheters. Circulation. 2004;109:2432-2439.

9. Nagueh SF, Sun H, Kopelen HA, Middleton KJ, Khoury DS. Hemodynamic determinants of the mitral annulus diastolic velocities by tissue Doppler. J Am Coll Cardiol. 2001;37:278-285.

10. Sohn DW, Chai IH, Lee DJ, Kim HC, Kim HS, Ko BH, et al. Assessment of mitral annulus velocity by Doppler tissue image in the evaluation of left ventricular diastolic function. J Am Coll Cardiol. 1997;30:474-480.

11. Nagueh SF, Middleton KJ, Kopelen HA, Zoghbi WA, Quinones MA. Doppler tissue imaging: A noninvasive technique for evaluation of left ventricular relaxation and estimation of filling pressures. J Am Coll Cardiol. 1997;30:1527-1533.

12. Ono M, Tanabe K, Asanuma T, Yoshitomi H, Shimizu H, Ohta Y, et al. Doppler echocardiography-derived index of myocardial performance (TEI index)-comparison with brain natriuretic peptide levels in various heart disease. Jpn Circ J. 2001;65: 637-642.

13. Senni M, Rodeheffer R, Tribouilloy CM, Evans JM, Jacobsen SJ, Bailey KR, et al. Use of echocardiography in the management of congestive heart failure in the community. J Am Coll Cardiol. 1999;33:164-170.

14. Zile M, Brutsaert D. New concepts in diastolic dysfunction and diastolic heart failure: Park I. Diagnosis, prognosis, and measurements of diastolic function. Circulation. 2002;105:1387-1393.

15. Maisel AS, McCord J, Nowak RM, Hollander JE, Wu AH, Duc P, et al. Breathing Not Properly Multinational Study Investigators. Bedside B-Type natriuretic peptide in the emergency diagnosis of heart failure with reduced or preserved ejection fraction. Result from the Breathing Not Properly Multinational Study. J Am Coll Cardiol. 2003;41(11):2010-2017.

16. Schiller NB, Shah PM, Crawford M, Demaria A, Devereux R, Feigenbaum $\mathrm{H}$, et al. Recommendations for quantification of the left ventricle by two-dimensional echocardiography. J Am Soc Echocardriogr. 1989;2:358-367.

17. Appleton CP, Jensen JL, Hatle LK, Oh JK. Doppler evaluation of left and right ventricular diastolic function: a technical guide for obtaining optimal flow velocity recordings. J Am Soc Echocardiogr. 1997;10:271-291.

18. Cowie MR, Mendez GF. BNP and congestive heart failure. Curr Probl Cardiol 2003;44:264-310.

19. Tomas J, Stefan J, Bertil L, Nina J, Mats S, Per V, et al. Natriuretic peptides in unstable coronary artery disease. Eur Heart J.
2004;25:1486-1493.

20. Yasue H, Yoshimura M, Sumida H, Kikuta H, Kuqiyama K, Jougasaki M, et al. Localization and mechanism of secretion of B-type natriuretic peptide in comparison with those of A-type natriuretic peptide in normal subjects and patients with heart failure. Circulation. 1994;90:195-203.

21. McGregor A, Richards M, Espiner E. Brain natriuretic peptide administered to man: Actions and metabolism. J Clin Endocrinol Metab. 1990;70:1103-1107.

22. Magga J, Vuolteenaho O, Tokola H. Involvement of transcriptional and posttranscriptional mechanisms in cardiac overload-induced increase of B-type natriuretic peptide gene expression. Circ Res. 1997;81:694-702.

23. Yoshibayashi M, Kamiya T, Saito Y. Plasma brain natriuretic peptide concentration in healthy children from birth to adolescence: marked and rapid increase after birth. Eur J Endocrinol. 1995;133:207-209.

24. Koglin J, Pehlivanli S, Schwaiblamir M, Vogeser M, Cremer P, von Scheidt W. Role of brain natriuretic peptide in risk stratification of patients with congestive heart failure. J Am Coll Cardiol. 2001;38:1934-1941.

25. Vasan RS, Benjamin EJ, Levy D. Prevalcence, clinical features and prognosis of diastolic heart failure: an epidemiologic perspective. J Am Coll Cardiol. 1995;26:1565-1574.

26. Senni M, Tribouilloy CM, Rodeheffer RJ, Jacobsen SJ, Evans JM, Bailey KR, et al. Congestive heart failure in the community: a study of all incident cases in Olmstead County, Minnesota, in 1991. Circulation. 1998;98:2282-2289.

27. Dao Q, Krishnaswamy P, Kazanegra R, Harrison A, Amirnovin $\mathrm{R}$, Lenert L, et al. Utility of B-type natriuretic peptide in the diagnosis of $\mathrm{CHF}$ in an urgent care setting. J Am Coll Cardiol. 2001;37;379-385.

28. Morrison KL, Harrison A, Krishnaswamy P, Kazanegra R, Clopton P, Maisel A. Utility of a rapid B-natriuretic peptide assay in differentiating CHF from lung disease in patients presenting with dyspnea. J Am Coll Cardiol. 2002;39:202-209.

29. Davies MK, Gibbs CR, Lib YM. ABC of heart failure; investigation. BMJ. 2003;320:297-300.

30. Isaaz K, Thompson A, Ethevenot G, Cloez JL, Brembilla B, Pernot C. Doppler echocardiographic measurement of low velocity motion of the left ventricular posterior wall. Am J Cardiol. 1989;64:66-75.

31. Lubien E, Demaria A. Krishnaswamy P, Clopton P, Koon J, Kazanegra R, et al. Utility of B-natriuretic peptide in detecting diastolic dysfunction: comparison with doppler velocity recordings. Circulation. 2002;105:595-601. 